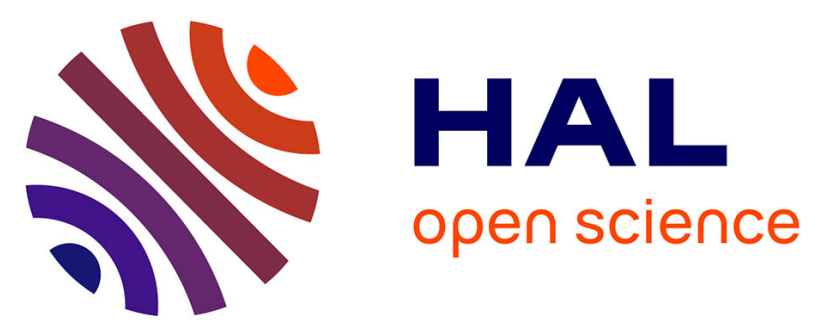

\title{
Fully weekly antituberculosis regimen: a proof-of-concept study
}

Fatma Kort, Laure Fournier Le Ray, Aurélie Chauffour, Vincent Jarlier, Nacer Lounis, Koen Andries, Alexandra Aubry, Lorenzo Guglielmetti, Nicolas Veziris

\section{- To cite this version:}

Fatma Kort, Laure Fournier Le Ray, Aurélie Chauffour, Vincent Jarlier, Nacer Lounis, et al.. Fully weekly antituberculosis regimen: a proof-of-concept study. European Respiratory Journal, 2020, 56 (3), pp.1902502. 10.1183/13993003.02502-2019 . hal-02962259

\section{HAL Id: hal-02962259 \\ https://hal.sorbonne-universite.fr/hal-02962259}

Submitted on 9 Oct 2020

HAL is a multi-disciplinary open access archive for the deposit and dissemination of scientific research documents, whether they are published or not. The documents may come from teaching and research institutions in France or abroad, or from public or private research centers.
L'archive ouverte pluridisciplinaire $\mathbf{H A L}$, est destinée au dépôt et à la diffusion de documents scientifiques de niveau recherche, publiés ou non, émanant des établissements d'enseignement et de recherche français ou étrangers, des laboratoires publics ou privés. 


\section{Fully weekly antituberculosis regimen: a proof-of-concept study}

Fatma Kort ${ }^{1}$, Laure Fournier Le Ray ${ }^{1}$, Aurélie Chauffour ${ }^{1}$, Vincent Jarlier ${ }^{1,2}$, Nacer Lounis $^{3}$, Koen Andries ${ }^{3}$, Alexandra Aubry ${ }^{1,2}$, Lorenzo Guglielmetti ${ }^{1,2}$, and Nicolas Veziris ${ }^{1,2,4}$

1 Sorbonne Université, INSERM, U1135, Centre d'Immunologie et des Maladies Infectieuses, Cimi-Paris, équipe 13, F-75013, Paris, France

2 APHP, Groupe Hospitalier Universitaire Sorbonne Université, Hôpital PitiéSalpêtrière, Centre National de Référence des Mycobactéries et de la Résistance des Mycobactéries aux Antituberculeux, F-75013 Paris, France

${ }^{3}$ Janssen R\&D, Beerse, Belgium

${ }^{4}$ APHP, Groupe Hospitalier Universitaire Sorbonne Université, Hôpital Saint-Antoine, Département de Bactériologie, F-75012 Paris, France

Keywords: Tuberculosis, Bedaquiline, Rifapentine, Directly Observed Therapy, Compliance

Corresponding author e-mail: nicolas.veziris@sorbonne-universite.fr

This work was supported by a grant from 'Fonds de dotation Recherche en Santé Respiratoire' and by a grant from Janssen. 


\section{ABSTRACT}

Background: WHO recommends supervising the treatment of tuberculosis. Intermittent regimens have the potential to simplify the supervision and improve compliance. Our objective was to analyze the sterilizing activity of once-weekly regimens based on drugs with a long half-life, bedaquiline and rifapentine, in a murine model of tuberculosis.

Methods: 300 Swiss mice were intravenously infected with 10exp6 Colony Forming Unit (CFU) of Mycobacterium tuberculosis H37Rv. Mice were treated once-weekly by regimens containing: a) bedaquiline, rifapentine and pyrazinamide (BPZ); b) BPZ plus moxifloxacin (BPZM); c) BPZM plus clofazimine (BPZMC); d) the standard daily regimen of tuberculosis. All regimens were given for 4 or 6 months. Bactericidal and sterilizing activity were assessed.

Results: after 2 months of treatment, the mean log10 CFU count in lungs was $0.76 \pm 0.60 \log 10$ in mice treated by the daily control regimen and negative in all mice treated by once-weekly regimens $(p<0.05$ compared to the daily control). All mice had negative lung cultures on completion of either 4 or 6 months of treatment, whereas 3 months after 4 and 6 months of treatment respectively, the relapse rate was $64 \%$ and $13 \%$ in the standard daily regimen, $5 \%$ and $0 \%$ in BPZ, $0 \%$ and $0 \%$ in BPMZ and $0 \%$ and $5 \%$ in BPMZC ( $p<0.05$ for all once-weekly regimens vs 4-month daily control, $p>0.05$ for all once-weekly regimens vs 6 -month daily control).

Conclusions: BPZ-based once-weekly regimens have higher sterilizing activity than the standard daily regimen and could greatly simplify treatment administration and possibly shorten the duration of tuberculosis treatment. 


\section{INTRODUCTION}

The treatment of drug-susceptible tuberculosis (TB) is based on a four-drug combination given for 6 months that has not changed for the last 40 years despite evidence that it was not optimally designed [1]. The complexity and length of this regimen limits treatment compliance and this can be the cause of treatment failure and emergence of drug resistance. Indeed, a study has shown that, in a daily regimen, $\leq 90 \%$ adherence significantly increases the rate of unfavorable outcome [2, 3].

In recent years, multiple clinical trials have been conducted in order to reduce the duration of TB treatment. These efforts have not been successful with fluoroquinolones [4-6] and are currently ongoing with daily rifapentine and high-dose rifampin [7-9], as well as with new drugs such as bedaquiline and pretomanid [10, 11]. However, reducing the duration of treatment is not the only way to simplify the treatment and its supervision. Another approach is to space out drug administration. Current treatment regimens are given either daily or twice- or thrice-weekly. These intermittent regimens are based on old studies and may not be as active as the daily one. Efforts have been conducted in order to develop once-weekly regimens based on drugs with a long half-life [12-14]. Some of these studies have been designed and conducted based on the use of a long half-life rifamycin, rifapentine. The first studies have not been successful because rifapentine was combined with isoniazid, a drug with short half-life. Thus, the once-weekly combination of isoniazid and rifapentine was indeed a rifapentine monotherapy for 6 days out of 7 and has led to treatment failure with selection of rifamycin-resistant mutants [15]. In order to avoid this risk, rifapentine should be combined with at least one companion drug with a long half-life, 
or be used only in cases with low bacillary burden to reduce the risk of treatment failure and selection of drug resistant mutants. Two different studies have demonstrated the efficacy of such strategies. In the first one, a randomized controlled clinical trial, an experimental arm containing rifapentine combined with moxifloxacin once-weekly during the 4 months of treatment continuation achieved non-inferiority compared to the daily control regimen [6]. In a second clinical trial, a rifapentineisoniazid weekly combination was successfully used for the treatment of latent TB infection [16-18]. Bedaquiline is a new anti-TB drug which has been mainly evaluated for the treatment of drug-resistant TB [19-22]. However, it has a very long half-life and could thus be a good candidate for a once-weekly regimen in combination with rifapentine, despite the known drug-drug interactions between bedaquiline and rifamycins. Since for both bedaquiline and rifapentine the main parameter predicting efficacy is the area under curve (AUC), a weekly regimen should be as active as daily one given that the weekly AUC is the same [23-25].

We previously demonstrated in a murine model of TB that once-weekly regimens based on the rifapentine-bedaquiline combination have higher bactericidal activity than the standard daily regimen after 1 and 2 months [26]. The objective of the present study was to evaluate the sterilizing activity of such regimens over the whole duration of treatment. 


\section{METHODS}

\section{Antimicrobial Agents}

Bedaquiline was provided by Janssen. The other compounds were purchased from the following manufacturers: rifampin from Sandoz, isoniazid from Galien, pyrazinamide from Sanofi, moxifloxacin from Eurogenerics, clofazimine from Sigma and rifapentine from Carbosynth.

Drugs were diluted in water containing $0.05 \%$ agar, except for bedaquiline which was diluted in aqueous 20\% 2-hydroxypropyl- $\beta$-cyclodextrin.

Drugs suspensions were prepared weekly except for rifampin (once every two weeks) and bedaquiline (once for the whole experiment), and were stored at $4^{\circ} \mathrm{C}$.

\section{Ethics}

The study was reviewed by ethical committee Charles Darwin and conducted under approval of Ministère de l'Enseignement Supérieur de la Recherche et de l'Innovation No $123802017112809414820 v 3$.

\section{Mycobacterium tuberculosis strain}

The H37Rv strain of M. tuberculosis was grown on Lowenstein-Jensen medium. This strain was obtained from a lung of an untreated mouse of a previous experiment stored at $-80^{\circ} \mathrm{C}$ [27]. Minimal inhibitory concentrations of drugs used in this experiment are presented in table $\mathrm{S} 1$.

Colonies were subcultured in Dubos broth plus $10 \%$ oleic acid-albumin-dextrosecatalase (OADC) for 7 days at $37^{\circ} \mathrm{C}$. The turbidity of the resulting suspension was 
adjusted with normal saline to match that of standard $1 \mathrm{mg} / \mathrm{ml}$ suspension of Mycobacterium bovis BCG and was further diluted with normal saline to obtain a suspension for mouse inoculation containing $2.06 \times 10^{6}$ Colony Forming Unit (CFU)/ml.

\section{Intravenous infection}

Three hundred six-week-old Swiss female mice were purchased from the Janvier Breeding Center. They were intravenously infected in the tail vein with $0.5 \mathrm{ml}$ of bacterial suspension containing $1.03 \times 10^{6} \mathrm{CFU}$ of Mycobacterium tuberculosis H37Rv. Intravenous infection has been historically used in the laboratory and has shown a better correlation with relapses in clinical trials than aerosol infection ([28, 29]).

\section{Chemotherapy}

After infection, mice were randomized into eight groups (Table 1). The negative control group contained 40 untreated mice, of which 10 were sacrificed the day after infection (D-27), 20 were sacrificed at the beginning of the treatment (D0) and 10 were sacrificed at 2 months of treatment. In the positive control group, mice received the daily standard regimen of drug-susceptible TB: 2 months of rifampin $(R)$, isoniazid $(H)$ and pyrazinamide $(Z)$ followed by 2 or 4 months of $R$ and $H$. In the experimental groups mice were treated once-weekly with: a) bedaquiline (B), rifapentine $(P)$ and pyrazinamide $(Z)(B P Z)$; b) BPZ plus moxifloxacin (BPZM); c) BPZM plus clofazimine (BPZMC). Each experimental regimen was tested for two treatment durations: 4 and 6 months. 
Treatment began 4 weeks after infection (D0). Drugs were administrated by gavage, either 5 days per week or once-weekly, at the following dosing: $\mathrm{R} 10 \mathrm{mg} / \mathrm{kg}, \mathrm{H}$ $25 \mathrm{mg} / \mathrm{kg}$, Z $150 \mathrm{mg} / \mathrm{kg}$ once-a-day (daily control) or $300 \mathrm{mg} / \mathrm{kg}$ once-a-week (experimental regimens); B 62.5mg/kg; P 20mg/kg; M 200mg/kg; C 20mg/kg. R was administered one hour before the other drugs to avoid drug-drug interactions. Drug dosing were selected to provide areas under the curve (AUC) values in mice comparable with those achievable in human (table S2). For bedaquiline, since the AUC is the main parameter predictive of efficacy, a weekly dosing generates an efficacy equivalent to that of daily dosing given that the total weekly amount of drug is the same. As a consequence, and as demonstrated previously a $125 \mathrm{mg} / \mathrm{kg}$ dosing once-weekly generates the same bactericidal activity as a $25 \mathrm{mg} / \mathrm{kg}$ dosing 5 times a week [23, 26]. The $25 \mathrm{mg} / \mathrm{kg}$ dose in the mouse generates an AUC of $19 \mathrm{mcg} \cdot \mathrm{h} / \mathrm{ml}$, thus a $125 \mathrm{mg} / \mathrm{kg}$ dosing should generate an AUC around $100 \mathrm{mcg} \cdot \mathrm{h} / \mathrm{ml}$. Since rifapentine reduces by $50 \%$ the AUC of bedaquiline in human and since this interaction does not exist in mouse, we used a half weekly dosing of bedaquiline in order to mimic the interaction seen in human [30,31]. Such dosing should generate and AUC close to $50 \mathrm{mcg} \cdot \mathrm{h} / \mathrm{ml}$ after a single dose of bedaquiline which corresponds to $50 \%$ of the AUC of bedaquiline after a single dose of $700 \mathrm{mg}$ of bedaquiline in human [32]. Bedaquiline undergoes accumulation both in murine model and in human leading to a doubling of the AUC after multiple doses (tables S3 and S4).

\section{Assessment of treatment efficacy}

Treated mice were sacrificed through cervical elongation at 2 months and at the end of the treatment (4 or 6 months) to assess bactericidal activity. Survival rate, mean spleen weights, gross lung lesions and mean lung CFU were analyzed. Lung CFU 
were determined by plating three serial 10 -fold dilutions of homogenized suspensions onto triplicate Lowenstein-Jensen slants that were incubated at $37^{\circ} \mathrm{C}$ for 6 weeks. Treated mice were sacrificed 3 months after treatment completion to assess sterilizing activity. Mean spleen weights, gross lung lesions and proportion of relapsing mice with positive lung culture (relapsing mice) were analyzed.

\section{Statistical analysis}

Mean spleen weights and lung CFU were compared using the Mann-Whitney's test. Proportions of mice with a positive $M$. tuberculosis culture from lung tissue 3 months after the completion of treatment were compared using the Fisher's test. Mice with contaminated lung cultures were excluded from analysis.

Statistical tests have been performed with BioStaTGV (https://biostatgv.sentiweb.fr/).

\section{Gene sequencing}

Among mice relapsing 3 months after treatment completion in the experimental groups, gene sequencing was performed on colonies grown on Lowenstein-Jensen slants for Rv0678, atpE, rpoB, pncA, gyrA and gyrB genes as previously described (table S5). 


\section{RESULTS}

\section{Survival rates}

Among untreated mice, 1/10 died on day 56, the others were sacrificed at 2 months. Among treated mice, some died of gavage accidents: 7/70 in BPZ group, 5/70 in BPZM group and 2/70 in BPZMC group. The proportion of gavage accidents was not different between daily and weekly groups, ( $p>0.05$ Fischer's exact test).

\section{Mean spleen weights}

The day after infection (D-27), the mean spleen weight was $152 \pm 20 \mathrm{mg}$ and increased to $413 \pm 250 \mathrm{mg}$ four weeks later (D0). After 2 months of treatment, the mean spleen weight decreased, although not significantly so, across all treated groups.

The mean spleen weight did not differ significantly between mice treated 2 months and mice at the end of treatment ( 4 or 6 months), except between mice treated 2 months and mice treated 4 months in the BPZMC group $(259 \pm 76 \vee 164 \pm 37, p=$ 0.006). The mean spleen weight was similar between mice sacrificed at 7 months ( 3 months after the 4-month treatment completion) and at 4 months. The mean spleen weight of mice sacrificed at 9 months ( 3 months after the 6 -months treatment completion) was significantly lower than at 6 months in once-weekly regimen groups, but not in daily standard regimen group.

\section{Bactericidal activity}

The mean CFU count in the lungs was $2.30 \pm 0.66 \log 10$ the day after infection (D27) and increased significantly to $4.60 \pm 1.26 \log 10$ at the beginning of the treatment 
(D0) $(p=0.007)$ (Table 2). After 2 months of treatment, all infected and untreated mice were sacrificed and their mean lung CFU count was $6.03 \pm 1.70 \log 10$.

The bactericidal activity was significantly greater in the once-weekly regimen groups than in the daily standard regimen group after 2 months of treatment: the mean lung CFU count was $0.76 \pm 0.60 \log 10$ in the daily standard regimen group (with 6/9 positive mice), and negative in all mice in the BPZ, BPZM and BPZMC groups ( $p=0.008, p=0.005$ and $p=0.003$ respectively as compared to daily control regimen). On completion of the 4-month and 6-month treatments, all treated mice, either with the daily standard regimen or with the once-weekly regimens, had a negative lung culture.

\section{Sterilizing activity}

After 4 months of treatment and 3 months of follow-up, 9 out of 14 mice (64\%) relapsed in the daily standard regimen group versus only 1 out of 19 mice $(5 \%)$ in the BPZ group and none out of 20 mice in the BPZM and BPZMC groups, respectively (Figure). The mean lung CFU counts in the relapsing mice were $2.19 \pm 0.75 \log 10$ in the standard regimen group and $1.52 \log 10$ in the positive mouse of the BPZ group. The relapse rate 3 months after 4 months of once-weekly treatment with BPZ, BPZM and BPZMC was significantly lower than after 4 months of daily standard treatment $(p<0.001)$ (table 2).

After 6 months of treatment and 3 months of follow-up, 2 out of 15 mice (13\%) relapsed in the daily standard regimen group versus 1 out of $19(5 \%)$ in the BPZMC group, with $0.93 \pm 1.31 \log 10$ and $2.44 \log 10$ lung CFU counts, respectively, and no relapse in the BPZ and BPZM groups. The difference in the relapse rate between 6 
months of daily standard regimen and 6 months of weekly regimen with BPZ, BPZM or BPZMC ( $p=0.32, p=0.32$ and $p=0.93$, respectively), or between 6 months of daily standard regimen and 4 months of weekly regimen with BPZ, or BPZM or BPZMC $(p=0.57, p=0.18$ and $p=0.18$, respectively), did not achieve statistical significance.

In the mouse that relapsed at 6 months of treatment and 3 months of follow-up in the BPZMC group, Rv0678, atpE, rpoB, pncA, gyrA and gyrB genes sequencing did not show any mutation. 


\section{Discussion}

This study demonstrates, to our knowledge for the first time, that once-weekly 4- or 6-month regimens based on the bedaquiline-pyrazinamide-rifapentine combination are at least as active as the 6-month daily standard regimen of tuberculosis in a murine model.

In a previous experiment in this model, we showed that the bactericidal activity of bedaquiline is the same whatever the frequency of administration (once-weekly, twice-weekly or 5/week), provided that the total weekly dose is the same [26]. However, in this previous study, we did not take into account the pharmacokinetic interaction between rifapentine and bedaquiline. Indeed, it has been shown later that rifapentine reduces bedaquiline AUC by $50 \%$ [33]. As a consequence, in the current study we reduced the bedaquiline weekly dose by half, from 125 to $62.5 \mathrm{mg} / \mathrm{kg}$, in order to mimic the AUC reduction seen in humans in presence of rifapentine and that does not exist in mouse [34].

Despite this drug-drug interaction, we believe that there is a clear benefit in combining these two drugs. We showed previously that in a daily regimen, the most active combinations of bedaquiline included rifampin and pyrazinamide [28]. A daily regimen of bedaquiline, pyrazinamide and rifapentine given for just 3 months resulted in a similar proportion of relapses as the standard regimen after 6 months [35]. As these drugs all have potent sterilizing activities, it is not surprising that their combination is very active.

In the current study, all three bedaquiline-rifapentine-pyrazinamide once-weekly groups showed superiority compared to standard daily regimen in terms of bactericidal activity at 2 months and of sterilizing activity at 4 months of treatment and 3 months of follow-up. At 6 months of treatment and 3 months of follow-up, the 
difference in bactericidal and sterilizing activity was not significant anymore, but at this point the relapse rate of the control regimen was low (13\%). Showing a statistically significant difference might require a higher number of individuals per arm. In addition, it must be underlined that the relapse rate of the once-weekly test regimens after 4 months was not different from that of the control regimen after 6 months. It is therefore possible that a bedaquiline-rifapentine-pyrazinamide regimen may reduce both the frequency of drug administration and the total duration of treatment.

Based on previous studies, we hypothesized that the addition of clofazimine and moxifloxacin could increase the sterilizing activity of the bedaquiline-rifapentinepyrazinamide combination $[34,36,37]$. In our study, no difference was shown in the groups treated with BPZ plus M and MC. This might be partially explained by the high sterilizing activity of the BPZ regimen. At least 80 mice per group and per time-point sacrifice would be required in order to show a $20 \%$ statistical difference. Similarly, in another study testing daily treatment with BPZ, the addition of M did not increase the sterilizing activity of the regimen [35].

Based on our knowledge of the anti-TB chemotherapy, an initial "intensive phase" with daily treatment could be warranted before switching to once-weekly dosing. Such daily intensive phase could rapidly reduce the bacillary load. This is unlikely to occur with a once-weekly bedaquiline-based regimen, given the delayed early bactericidal activity exerted by bedaquiline [38, 39]. In our opinion, moxifloxacin could be included in such a clinical trial regimen, despite the lack of additive effect shown in our study. Indeed, moxifloxacin has demonstrated early bactericidal activity [40]; in addition, the long half-life of this drug makes it a good companion drug for rifapentine [6]. Regarding clofazimine, at present, there has been no clinical proof of its activity 
in the context of drug-susceptible tuberculosis and the skin pigmentation can be a limit to its use even if it may be less pronounced if given weekly. On the other hand, data from murine studies support the use of clofazimine against drug-susceptible tuberculosis [36, 41]; in addition, clofazimine has also been shown to act synergistically with bedaquiline in a murine model [36] and to have a long half-life [42, 43], making it an interesting choice for weekly regimens. However, bedaquiline, clofazimine and moxifloxacin are all known to prolong the QT interval and should be used carefully in patients either in clinical trials or in the programmatic use.

When discussing findings from preclinical models, a crucial question is to what extent they are predictive for treatment outcomes in humans. The model used here (IV infected swiss mice) can be considered as a very conservative one and is therefore not expected to generate results which are too "optimistic", compared to what eventually is seen in humans [44]. This was illustrated in the evaluation of the ability of fluoroquinolones to shorten the treatment. While in a model of aerosol-infected $\mathrm{BALB} / \mathrm{c}$ mice the 4-month moxifloxacin-based regimen was as active as the standard 6-month daily regimen, this was not the case in our model [28, 29]. Ultimately, the clinical studies confirmed the inferiority of the 4-month moxifloxacin (REMOX study) and Gatifloxacin (OFLOTUB study) regimen [4-6].

Another limit is the number of animals used in the study, which, although high for a murine study (300 mice), remains low compared to the expected sample size of a clinical trial (approximately 500 patients/arm). Thus this study as others conducted in murine models, must be seen as a proof-of-concept that needs to be confirmed in a clinical trial.

Also toxicity in relation with high peak serum level the day of drug intake may be a limit. Finally, the bedaquiline AUC reduction in presence of rifapentine may be seen 
as a limitation since this reduction may vary from patient to patient and generate heterogeneous exposures to bedaquiline, requiring therapeutic drug monitoring [45]. A possible solution would be to replace rifapentine with another drug with a long halflife: moxifloxacin which has shown interesting activity combined with bedaquiline without rifapentine or also other newly approved drugs or under development [34, 46-48]. Whatever the choice, the potential candidate should have at least as strong sterilizing properties as rifamycins and a preliminary pharmacokinetic study assessing the different drug interactions in human would be required before starting a therapeutic trial.

Up to now, bedaquiline development has focused on drug-resistant tuberculosis, similarly to two other recently-approved drugs, delamanid and pretomanid. We believe that these new drugs could also play a role in improving treatment of drugsusceptible TB. Overall, the development of intermittent regimens has been somewhat neglected in favor of shortened regimens. It should be recalled that to date, whereas all shorter fluoroquinolone-based regimens failed to show noninferiority to the standard daily 6-month regimen, a regimen including once-weekly rifapentine-moxifloxacin during the continuation phase managed to show noninferiority [6]. If confirmed in a clinical trial, such a weekly regimen would reduce the number of days with drug intakes from 182 to 26 . A daily regimen would have to be reduced to less than one month in order to reach a similar low number of drug intakes. Once weekly regimens should be explored to increase compliance. 
Tables and Figures

Table 1. Experimental design

\begin{tabular}{|c|c|c|c|c|c|c|c|c|}
\hline \multirow{2}{*}{$\begin{array}{l}\text { Frequency } \\
\text { of drug } \\
\text { administration }\end{array}$} & \multirow{2}{*}{$\begin{array}{c}\text { Treatment } \\
\text { group }\end{array}$} & \multicolumn{7}{|c|}{ No of mice sacrificed at: } \\
\hline & & D-27 & Do & 2Mo & 4Mo & 6Mo & 4+3Mo & $6+3 \mathrm{Mo}$ \\
\hline & Untreated & 10 & 20 & 10 & & & & \\
\hline 5 days $/ 7$ & $2 \mathrm{RHZ} / 4 \mathrm{RH}$ & & & 10 & & 10 & & 30 \\
\hline \multirow{7}{*}{1 day $/ 7$} & $4 \mathrm{BPZ}$ & & & 10 & 10 & & 20 & \\
\hline & $6 \mathrm{BPZ}$ & & & & & 10 & & 20 \\
\hline & $4 \mathrm{BPMZ}$ & & & 10 & 10 & & 20 & \\
\hline & $6 \mathrm{BPMZ}$ & & & & & 10 & & 20 \\
\hline & 4 BPMZC & & & 10 & 10 & & 20 & \\
\hline & 6 BPMZC & & & & & 10 & & 20 \\
\hline & Total & 10 & 20 & 50 & 30 & 40 & 60 & 90 \\
\hline
\end{tabular}

$\mathrm{R}$ : rifampin, $\mathrm{H}$ : isoniazid, $\mathrm{Z}$ : pyrazinamide, $\mathrm{B}$ : bedaquiline, $\mathrm{P}$ : rifapentine, $\mathrm{M}$ : moxifloxacin, C: clofazimine 
Table 2. Bacterial counts in the lungs of mice and proportion of mice with positive lung culture after 2, 4 and 6 months of treatment in murine tuberculosis ${ }^{\dagger}$

\begin{tabular}{lcccccc}
\hline \multirow{2}{*}{ Group } & \multicolumn{5}{c}{ Bacterial counts (mean log10 CFU \pm SD) } \\
& Proportion of mice with positive culture \\
& Day 0 & $\mathbf{2 ~ M o}$ & $\mathbf{4}$ Mo & $\mathbf{6 ~ M o}$ & $\mathbf{4 ~ M o + 3}$ & $\mathbf{6 ~ M o + 3}$ \\
\hline \multirow{2}{*}{ Untreated } & $4,60 \pm 1,26$ & $6,03 \pm 1,70$ & - & - & & \\
& $(20 / 20)$ & $(9 / 9)$ & & & & \\
RHZ/RH & & $0.76 \pm 0.60$ & 0 & 0 & $2.19 \pm 0.75$ & $0.93 \pm 1.31$ \\
& - & $(6 / 9)$ & $(0 / 5)$ & $(0 / 5)$ & $(9 / 14)$ & $(2 / 15)$ \\
BPZ & - & $0^{*}$ & 0 & 0 & 1.52 & 0 \\
& - & $(0 / 8)$ & $(0 / 7)$ & $(0 / 8)$ & $(1 / 19)^{*}$ & $(0 / 17)$ \\
BPZM & - & $0^{*}$ & 0 & 0 & 0 & 0 \\
& & $(0 / 9)$ & $(0 / 7)$ & $(0 / 10)$ & $(0 / 20)^{*}$ & $(0 / 17)$ \\
BPZMC & - & $0^{*}$ & 0 & 0 & 0 & 2.44 \\
& & $(0 / 10)$ & $(0 / 9)$ & $(0 / 9)$ & $(0 / 20)^{*}$ & $(1 / 19)$ \\
\hline
\end{tabular}

$\mathrm{R}$ : rifampin, $\mathrm{H}$ : isoniazid, $\mathrm{Z}$ : pyrazinamide, $\mathrm{B}$ : bedaquiline, $\mathrm{P}$ : rifapentine, $\mathrm{M}$ : moxifloxacin, C: clofazimine,

*: $p<0.05$ vs control arm RHZ,

†Mice with contaminated lung culture were excluded from the analysis, $2 \mathrm{RHZ}(1$ at $2 \mathrm{Mo}$ and 1 at $4 \mathrm{Mo}+3$ ), $4 \mathrm{BPZ}$ (1 at $2 \mathrm{Mo}, 1$ at $4 \mathrm{Mo}$ and 2 at $6 \mathrm{Mo}+3$ ), $2 \mathrm{BPZM}$ (1 at 2 $\mathrm{Mo}, 1$ at $6 \mathrm{Mo}+3$ ) and $1 \mathrm{BPZMC}$ (at $4 \mathrm{Mo}$ ) 
Figure: proportion (\%) of mice with positive lung culture after 2, 4 and 6 months of treatment in murine tuberculosis 


\section{REFERENCES}

1. van Ingen J, Aarnoutse RE, Donald PR, Diacon AH, Dawson R, Plemper van Balen G, Gillespie SH, Boeree MJ. Why Do We Use 600 mg of Rifampicin in Tuberculosis Treatment? Clin. Infect. Dis. 2011; 52: e194-e199.

2. Imperial MZ, Nahid P, Phillips PPJ, Davies GR, Fielding K, Hanna D, Hermann D, Wallis RS, Johnson JL, Lienhardt C, Savic RM. A patient-level pooled analysis of treatment-shortening regimens for drug-susceptible pulmonary tuberculosis. Nat. Med. 2018; 24: 1708-1715.

3. Srivastava S, Sherman C, Meek C, Leff R, Gumbo T. Pharmacokinetic Mismatch Does Not Lead to Emergence of Isoniazid- or Rifampin-Resistant Mycobacterium tuberculosis but to Better Antimicrobial Effect: a New Paradigm for Antituberculosis Drug Scheduling ${ }^{\nabla}$. Antimicrob. Agents Chemother. 2011; 55: 5085-5089.

4. Gillespie SH, Crook AM, McHugh TD, Mendel CM, Meredith SK, Murray SR, Pappas F, Phillips PPJ, Nunn AJ, REMoxTB Consortium. Four-month moxifloxacin-based regimens for drug-sensitive tuberculosis. N. Engl. J. Med. 2014; 371: 1577-1587.

5. Merle CS, Fielding K, Sow OB, Gninafon M, Lo MB, Mthiyane T, Odhiambo J, Amukoye E, Bah B, Kassa F, N'Diaye A, Rustomjee R, de Jong BC, Horton J, Perronne C, Sismanidis C, Lapujade O, Olliaro PL, Lienhardt C, OFLOTUB/Gatifloxacin for Tuberculosis Project. A four-month gatifloxacincontaining regimen for treating tuberculosis. N. Engl. J. Med. 2014; 371: 15881598.

6. Jindani A, Harrison TS, Nunn AJ, Phillips PPJ, Churchyard GJ, Charalambous S, Hatherill M, Geldenhuys H, Mcllleron HM, Zvada SP, Mungofa S, Shah NA, Zizhou S, Magweta L, Shepherd J, Nyirenda S, van Dijk JH, Clouting HE, Coleman D, Bateson ALE, McHugh TD, Butcher PD, Mitchison DA, RIFAQUIN Trial Team. High-dose rifapentine with moxifloxacin for pulmonary tuberculosis. N. Engl. J. Med. 2014; 371: 1599-1608.

7. Boeree MJ, Heinrich N, Aarnoutse R, Diacon AH, Dawson R, Rehal S, Kibiki GS, Churchyard G, Sanne I, Ntinginya NE, Minja LT, Hunt RD, Charalambous S, Hanekom M, Semvua HH, Mpagama SG, Manyama C, Mtafya B, Reither K, Wallis RS, Venter A, Narunsky K, Mekota A, Henne S, Colbers A, Balen GP van, Gillespie SH, Phillips PPJ, Hoelscher M. High-dose rifampicin, moxifloxacin, and SQ109 for treating tuberculosis: a multi-arm, multi-stage randomised controlled trial. Lancet Infect. Dis. [Internet] 2016 [cited 2016 Dec 6]; 0Available from: /journals/laninf/article/PIIS1473-3099(16)30274-2/abstract.

8. Dorman SE, Savic RM, Goldberg S, Stout JE, Schluger N, Muzanyi G, Johnson JL, Nahid P, Hecker EJ, Heilig CM, Bozeman L, Feng P-JI, Moro RN, MacKenzie W, Dooley KE, Nuermberger EL, Vernon A, Weiner M, Tuberculosis Trials Consortium. Daily rifapentine for treatment of pulmonary tuberculosis. A 
randomized, dose-ranging trial. Am. J. Respir. Crit. Care Med. 2015; 191: 333343.

9. Mourik BC, Svensson RJ, de Knegt GJ, Bax HI, Verbon A, Simonsson USH, de Steenwinkel JEM. Improving treatment outcome assessment in a mouse tuberculosis model. Sci. Rep. 2018; 8: 5714.

10. Dawson R, Diacon AH, Everitt D, van Niekerk C, Donald PR, Burger DA, Schall R, Spigelman M, Conradie A, Eisenach K, Venter A, Ive P, Page-Shipp L, Variava E, Reither K, Ntinginya NE, Pym A, von Groote-Bidlingmaier F, Mendel $\mathrm{CM}$. Efficiency and safety of the combination of moxifloxacin, pretomanid (PA824), and pyrazinamide during the first 8 weeks of antituberculosis treatment: a phase $2 \mathrm{~b}$, open-label, partly randomised trial in patients with drug-susceptible or drug-resistant pulmonary tuberculosis. Lancet Lond. Engl. 2015; 385: 17381747.

11. Tweed CD, Dawson R, Burger DA, Conradie A, Crook AM, Mendel CM, Conradie F, Diacon AH, Ntinginya NE, Everitt DE, Haraka F, Li M, van Niekerk $\mathrm{CH}$, Okwera A, Rassool MS, Reither K, Sebe MA, Staples S, Variava E, Spigelman M. Bedaquiline, moxifloxacin, pretomanid, and pyrazinamide during the first 8 weeks of treatment of patients with drug-susceptible or drug-resistant pulmonary tuberculosis: a multicentre, open-label, partially randomised, phase 2b trial. Lancet Respir. Med. 2019; 7: 1048-1058.

12. Grosset J, Lounis N, Truffot-Pernot C, O'Brien RJ, Raviglione MC, Ji B. Onceweekly rifapentine-containing regimens for treatment of tuberculosis in mice. Am J Respir Crit Care Med 1998; 157: 1436-1440.

13. Lenaerts AM, Chase SE, Chmielewski AJ, Cynamon MH. Evaluation of rifapentine in long-term treatment regimens for tuberculosis in mice. Antimicrob Agents Chemother 1999; 43: 2356-2360.

14. Dhillon J, Dickinson JM, Guy JA, Ng TK, Mitchison DA. Activity of two longacting rifamycins, rifapentine and FCE 22807, in experimental murine tuberculosis. Tuber. Lung Dis. Off. J. Int. Union Tuberc. Lung Dis. 1992; 73: 116-123.

15. Vernon A, Burman W, Benator D, Khan A, Bozeman L. Acquired rifamycin monoresistance in patients with HIV-related tuberculosis treated with onceweekly rifapentine and isoniazid. Tuberculosis Trials Consortium. Lancet 1999; 353: 1843-1847.

16. Sterling TR, Villarino ME, Borisov AS, Shang N, Gordin F, Bliven-Sizemore E, Hackman J, Hamilton CD, Menzies D, Kerrigan A, Weis SE, Weiner M, Wing D, Conde MB, Bozeman L, Horsburgh CR Jr, Chaisson RE. Three months of rifapentine and isoniazid for latent tuberculosis infection. N. Engl. J. Med. 2011; 365: 2155-2166.

17. Migliori GB, Sotgiu G, Rosales-Klintz S, Centis R, D'Ambrosio L, Abubakar I, Bothamley G, Caminero JA, Cirillo DM, Dara M, Vries G de, Aliberti S, DinhXuan AT, Duarte R, Midulla F, Solovic I, Subotic DR, Amicosante M, Correia 
AM, Cirule A, Gualano G, Kunst H, Palmieri F, Riekstina V, Tiberi S, Verduin R, Werf MJ van der. ERS/ECDC Statement: European Union standards for tuberculosis care, 2017 update. Eur. Respir. J. [Internet] 2018 [cited 2019 Dec 27]; 51 Available from: https://erj.ersjournals.com/content/51/5/1702678.

18. Rosales-Klintz S, Bruchfeld J, Haas W, Heldal E, Houben RMGJ, van Kessel F, Mandelbaum M, Matteelli A, Migliori GB, Oordt-Speets A, Solovic I, Vašáková M, Verver S, de Vlas SJ, Vonk Noordegraaf-Schouten MJM, de Vries G, Zenner $D$, van der Werf MJ. Guidance for programmatic management of latent tuberculosis infection in the European Union/European Economic Area. Eur. Respir. J. 2019; 53.

19. Vasilyeva I, Mariandyshev A, Kazennyy B, Davidavičienė E, Lounis N, Keim S, on behalf of the TMC207TBC3001 study group. Early access to bedaquiline for extensively drug-resistant (XDR) and pre-XDR tuberculosis. Eur. Respir. J. $2019 ; 54$.

20. Ndjeka N, Schnippel K, Master I, Meintjes G, Maartens G, Romero R, Padanilam X, Enwerem M, Chotoo S, Singh N, Hughes J, Variava E, Ferreira H, Te Riele J, Ismail N, Mohr E, Bantubani N, Conradie F. High treatment success rate for multidrug-resistant and extensively drug-resistant tuberculosis using a bedaquiline-containing treatment regimen. Eur. Respir. J. 2018; 52.

21. Migliori GB, Sotgiu G, Rosales-Klintz S, van der Werf MJ. European Union standard for tuberculosis care on treatment of multidrug-resistant tuberculosis following new World Health Organization recommendations. Eur. Respir. J. 2018; 52 .

22. Borisov SE, Dheda K, Enwerem M, Romero Leyet R, D'Ambrosio L, Centis R, Sotgiu G, Tiberi S, Alffenaar J-W, Maryandyshev A, Belilovski E, Ganatra S, Skrahina A, Akkerman O, Aleksa A, Amale R, Artsukevich J, Bruchfeld J, Caminero JA, Carpena Martinez I, Codecasa L, Dalcolmo M, Denholm J, Douglas P, Duarte R, Esmail A, Fadul M, Filippov A, Davies Forsman L, Gaga $\mathrm{M}$, et al. Effectiveness and safety of bedaquiline-containing regimens in the treatment of MDR- and XDR-TB: a multicentre study. Eur. Respir. J. 2017; 49.

23. Rouan M-C, Lounis N, Gevers T, Dillen L, Gilissen R, Raoof A, Andries K. Pharmacokinetics and Pharmacodynamics of TMC207 and Its N-Desmethyl Metabolite in a Murine Model of Tuberculosis. Antimicrob. Agents Chemother. 2012; 56: 1444-1451.

24. Sirgel FA, Fourie PB, Donald PR, Padayatchi N, Rustomjee R, Levin J, Roscigno G, Norman J, Mcllleron $\mathrm{H}$, Mitchison DA. The early bactericidal activities of rifampin and rifapentine in pulmonary tuberculosis. Am J Respir Crit Care Med 2005; 172: 128-135.

25. Jayaram R, Gaonkar S, Kaur P, Suresh BL, Mahesh BN, Jayashree R, Nandi V, Bharat S, Shandil RK, Kantharaj E, Balasubramanian V. Pharmacokineticspharmacodynamics of rifampin in an aerosol infection model of tuberculosis. Antimicrob Agents Chemother 2003; 47: 2118-2124. 
26. Veziris N, Ibrahim M, Lounis N, Chauffour A, Truffot-Pernot C, Andries K, Jarlier V. A Once-Weekly R207910-containing Regimen Exceeds Activity of the Standard Daily Regimen in Murine Tuberculosis. Am. J. Respir. Crit. Care Med. 2009; 179: 75-79.

27. Poissy J, Aubry A, Fernandez C, Lott M-C, Chauffour A, Jarlier V, Farinotti R, Veziris $\mathrm{N}$. Should moxifloxacin be used for the treatment of extensively drugresistant tuberculosis? An answer from a murine model. Antimicrob. Agents Chemother. 2010; 54: 4765-4771.

28. Ibrahim M, Truffot-Pernot C, Andries K, Jarlier V, Veziris N. Sterilizing activity of R207910 (TMC207)-containing regimens in the murine model of tuberculosis. Am. J. Respir. Crit. Care Med. 2009; 180: 553-557.

29. Nuermberger EL, Yoshimatsu T, Tyagi S, Williams K, Rosenthal I, O'Brien RJ, Vernon AA, Chaisson RE, Bishai WR, Grosset JH. Moxifloxacin-containing regimens of reduced duration produce a stable cure in murine tuberculosis. $\mathrm{Am}$. J. Respir. Crit. Care Med. 2004; 170: 1131-1134.

30. Rosenthal IM, Tasneen R, Peloquin CA, Zhang M, Almeida D, Mdluli KE, Karakousis PC, Grosset JH, Nuermberger EL. Dose-Ranging Comparison of Rifampin and Rifapentine in Two Pathologically Distinct Murine Models of Tuberculosis. Antimicrob. Agents Chemother. 2012; 56: 4331-4340.

31. Healan AM, Griffiss JM, Proskin HM, O'Riordan MA, Gray WA, Salata RA, Blumer JL. Impact of Rifabutin or Rifampin on Bedaquiline Safety, Tolerability, and Pharmacokinetics Assessed in a Randomized Clinical Trial with Healthy Adult Volunteers. Antimicrob. Agents Chemother. 2018; 62.

32. van Heeswijk RPG, Dannemann B, Hoetelmans RMW. Bedaquiline: a review of human pharmacokinetics and drug-drug interactions. J. Antimicrob. Chemother. 2014; 69: 2310-2318.

33. Winter H, Egizi E, Murray S, Erondu N, Ginsberg A, Rouse DJ, SeverynseStevens D, Pauli E. Evaluation of the Pharmacokinetic Interaction between Repeated Doses of Rifapentine or Rifampin and a Single Dose of Bedaquiline in Healthy Adult Subjects. Antimicrob. Agents Chemother. 2015; 59: 1219-1224.

34. Tasneen R, Li S-Y, Peloquin CA, Taylor D, Williams KN, Andries K, Mdluli KE, Nuermberger EL. Sterilizing Activity of Novel TMC207- and PA-824-Containing Regimens in a Murine Model of Tuberculosis ${ }^{\nabla}$. Antimicrob. Agents Chemother. 2011; 55: 5485-5492.

35. Andries K, Gevers T, Lounis N. Bactericidal potencies of new regimens are not predictive of their sterilizing potencies in a murine model of tuberculosis. Antimicrob Agents Chemother 2010; 54: 4540-4544.

36. Williams K, Minkowski A, Amoabeng O, Peloquin CA, Taylor D, Andries K, Wallis RS, Mdluli KE, Nuermberger EL. Sterilizing Activities of Novel Combinations Lacking First- and Second-Line Drugs in a Murine Model of Tuberculosis. Antimicrob. Agents Chemother. 2012; 56: 3114-3120. 
37. Veziris N, Lounis N, Chauffour A, Truffot-Pernot C, Jarlier V. Efficient Intermittent Rifapentine-Moxifloxacin-Containing Short-Course Regimen for Treatment of Tuberculosis in Mice. Antimicrob. Agents Chemother. 2005; 49: 4015-4019.

38. Rustomjee R, Diacon AH, Allen J, Venter A, Reddy C, Patientia RF, Mthiyane TCP, De Marez T, van Heeswijk R, Kerstens R, Koul A, De Beule K, Donald PR, McNeeley DF. Early Bactericidal Activity and Pharmacokinetics of the Diarylquinoline TMC207 in Treatment of Pulmonary Tuberculosis. Antimicrob. Agents Chemother. 2008; 52: 2831-2835.

39. Diacon AH, Dawson $R$, von Groote-Bidlingmaier $F$, Symons $G$, Venter A, Donald $P R$, van Niekerk C, Everitt D, Winter $H$, Becker $P$, Mendel CM, Spigelman MK. 14-day bactericidal activity of PA-824, bedaquiline, pyrazinamide, and moxifloxacin combinations: a randomised trial. Lancet 2012; 380: 986-993.

40. Gillespie SH, Gosling RD, Uiso L, Sam NE, Kanduma EG, McHugh TD. Early bactericidal activity of a moxifloxacin and isoniazid combination in smearpositive pulmonary tuberculosis. J Antimicrob Chemother 2005; 56: 1169-1171.

41. Saini V, Ammerman NC, Chang YS, Tasneen R, Chaisson RE, Jain S, Nuermberger E, Grosset JH. Treatment-Shortening Effect of a Novel Regimen Combining Clofazimine and High-Dose Rifapentine in Pathologically Distinct Mouse Models of Tuberculosis. Antimicrob. Agents Chemother. 2019; 63.

42. Holdiness MR. Clinical pharmacokinetics of clofazimine. A review. Clin. Pharmacokinet. 1989; 16: 74-85.

43. Swanson RV, Adamson J, Moodley C, Ngcobo B, Ammerman NC, Dorasamy A, Moodley S, Mgaga Z, Tapley A, Bester LA, Singh S, Grosset JH, Almeida DV. Pharmacokinetics and pharmacodynamics of clofazimine in a mouse model of tuberculosis. Antimicrob. Agents Chemother. 2015; 59: 3042-3051.

44. De Groote MA, Gilliland JC, Wells CL, Brooks EJ, Woolhiser LK, Gruppo V, Peloquin CA, Orme IM, Lenaerts AJ. Comparative studies evaluating mouse models used for efficacy testing of experimental drugs against Mycobacterium tuberculosis. Antimicrob. Agents Chemother. 2011; 55: 1237-1247.

45. Alffenaar J-WC, Akkerman OW, Tiberi S, Sotgiu G, Migliori GB. Should we worry about bedaquiline exposure in the treatment of multidrug-resistant and extensively drug-resistant tuberculosis? Eur. Respir. J. 2020; 55: 1901908.

46. Pethe K, Bifani P, Jang J, Kang S, Park S, Ahn S, Jiricek J, Jung J, Jeon HK, Cechetto J, Christophe T, Lee H, Kempf M, Jackson M, Lenaerts AJ, Pham H, Jones V, Seo MJ, Kim YM, Seo M, Seo JJ, Park D, Ko Y, Choi I, Kim R, Kim SY, Lim S, Yim S-A, Nam J, Kang H, et al. Discovery of Q203, a potent clinical candidate for the treatment of tuberculosis. Nat. Med. 2013; 19: 1157-1160.

47. Lamprecht DA, Finin PM, Rahman MA, Cumming BM, Russell SL, Jonnala SR, Adamson JH, Steyn AJC. Turning the respiratory flexibility of Mycobacterium tuberculosis against itself. Nat. Commun. 2016; 7: 12393. 
48. Salinger DH, Subramoney V, Everitt D, Nedelman JR. Population Pharmacokinetics of the Antituberculosis Agent Pretomanid. Antimicrob. Agents Chemother. 2019; 63. 